\title{
Anatomical variations on the origin of the dorsal scapular artery: about 58 dissections
}

\begin{abstract}
Introduction: The dorsal scapular artery (Arteria dorsalis scapulae) is often described as the last collateral branch of the subclavian axis. It anastomoses extensively with the transverse artery of the neck (arteria transversa cervicis) to irrigate the trapezius muscle. However, its origin can be very variable. The objective of this work was to study the different modalities of birth of the arteria dorsalis scapulae from the subclavian artery.
\end{abstract}

Material and methods: We performed dissection of 58 supraclavicular regions from 32 bodies preserved in a non-formalin solution rich in glycerine. The subclavian artery (arteria subclavia) was exposed, as well as all its collateral branches. The arteria dorsalis scapulae was identified by its location as collateral and its route, and then injected with a solution of methylene blue and gelatin.

Results: Our results were divided into 3 types according to the mode of birth and the branch of origin. In 21 cases, the arteria dorsalis scapulae and the arteria transversa cervicis were born from a common trunk stemming from the arteria subclavia (type I). In 27 cases, the arteria dorsalis scapulae was born directly from the arteria subclavia, while the arteria transversa cervicis came from the thyro-cervical trunk or truncus thyrocervicalis (type II). In 10 cases, the dorsalis scapulae and transversa cervicis arteries all represented collateral branches of the thyro-cervical trunk (type III).

Conclusion: The formation of the arteria dorsalis scapulae from the subclavian axis can present numerous anatomical variations. These variations must be taken into account during the surgery of flaps of the trapezius muscle.

Keywords: dorsal scapular artery, origin, anatomical variations, trapezius flaps
Volume 5 Issue 2 - 2018

\author{
Philippe Manyacka MA Nyemb, ${ }^{1,2}$ Christian \\ Fontaine, ${ }^{3}$ Xavier Demondion, ${ }^{3,4}$ Maurice \\ Demeulaere, ${ }^{3}$ Fabien Descamps, ${ }^{3}$ Jean-Marc \\ Ndoye $^{5}$ \\ 'Laboratory of Anatomy and Organogenesis, Gaston Berger \\ University, Sénégal \\ ${ }^{2}$ General Surgery Service, Regional Hospital, Sénégal \\ ${ }^{3}$ Laboratory of Anatomy, University of Lille, France \\ ${ }^{4}$ Department of Musculoskeletal Imaging, Lille University \\ Hospital, France \\ ${ }^{5}$ Laboratory of Anatomy and Organogenesis, Cheikh Anta Diop \\ University, Senegal
}

Correspondence: Philippe Manyacka MA Nyemb, Laboratory of Anatomy and Organogenesis, UFR 2S, BP 234, Gaston Berger University, Road of Ngallèlle, 234 Saint-Louis, Sénégal,Tel (+221) 7744543 I3, Email phil_manyacka@yahoo.fr

Received: January 01, 2018 | Published: April 18, 2018

\section{Introduction}

The arteria dorsalis scapulae is usually described as the last collateral branch of the subclavia arteria. In this case its origin is localized below the anterior scalene muscle (scalenus anterior). ${ }^{\text {S Some }}$ authors describe this artery as the deep branch of the arteria transversa cervicis, arising next to the anterior edge of the trapezius muscle. ${ }^{1}$ Irrespective of its origin, the arteria dorsalis scapulae represents the main vascular pedicle of the trapezius muscle and surrounding integuments. Any microvascular surgery in the trapezian region therefore implies an excellent knowledge of the anatomy of the arteria dorsalis scapulae whose origin - and therefore the path - can be very variable. ${ }^{2}$ The authors of this work report different birth modalities of the arteria dorsalis scapulae from its original trunks.

\section{Surgical anatomy}

According to the Mathes \& Nahai, ${ }^{3}$ the trapezius muscle receives type II vascularization with a primary pedicle from the transverse cervical artery and secondary pedicles issued from the occipital, intercostal and circumflex scapular perforating arteries.

The transverse cervical artery has a somewhat variable territory. However, its branches anastomose to those of the dorsal scapular artery to contribute to the vascularization of the trapezius, both in the muscle body itself and its integuments. Based on an anatomical study of 124 cadavers, ${ }^{4}$ the descending fibers receive branches from the occipital artery; the middle fibers and the lateral areas receive branches from the superficial branch of the transverse cervical artery; the ascending fibers receive branches from the dorsal scapular artery and the posterior intercostal arteries. Nevertheless, these vessels vastly anastomose with each other.

The dorsal scapular artery courses deep to the levator scapulae and rhomboid muscles. Branches then pierce the fascia separating the two rhomboid muscles (major and minor) and become superficial over the medial margin of the scapula. They form the dorsal scapular artery. This superficial branch penetrates the deep side of the trapezius and then gives off several cutaneous perforators that irrigate the skin covering the caudal portion of the trapezius - here it courses 1 to $2 \mathrm{~cm}$ from the muscle's lateral margin. The average diameter of the dorsal scapular artery is $2.7 \mathrm{~mm}$ proximally and at its origin, and $1.95 \mathrm{~mm}$ over the levator scapulae muscle. ${ }^{5}$ A deep branch of the dorsal scapular artery continues its descending trajectory under the rhomboid major muscle. This descending branch gives off several perforators to the rhomboid muscles, trapezius muscle and the overlying skin. ${ }^{2}$

The "posterior" scapular artery, studied in Salmons's book "Artères des muscles de la tête et du cou", plays a large role in the irrigation of the integuments (Figure 1). ${ }^{6,7}$

The trapezial artery, branch of this "posterior" scapular, gives two or three branches which perforate the trapezius muscle closely to the spine of the scapula and which reach the deep face of the skin. The trapezial artery (and consequently its cutaneous branches) can be provided by the arteria transversa cervicis ( $25 \%$ of cases) ${ }^{6,7}$

The sub-spinal artery, another branch of the "posterior" scapular, and the supraspinous artery, branch of the suprascapularis artery, 
anastomose below the trapezius And of these anastomosis is born a series of tiny branches which cross the insertion of the trapezius muscle and get lost in the periosteal network of the spine of the scapula. Some reach the skin. Abnormally, they can take a considerable size.

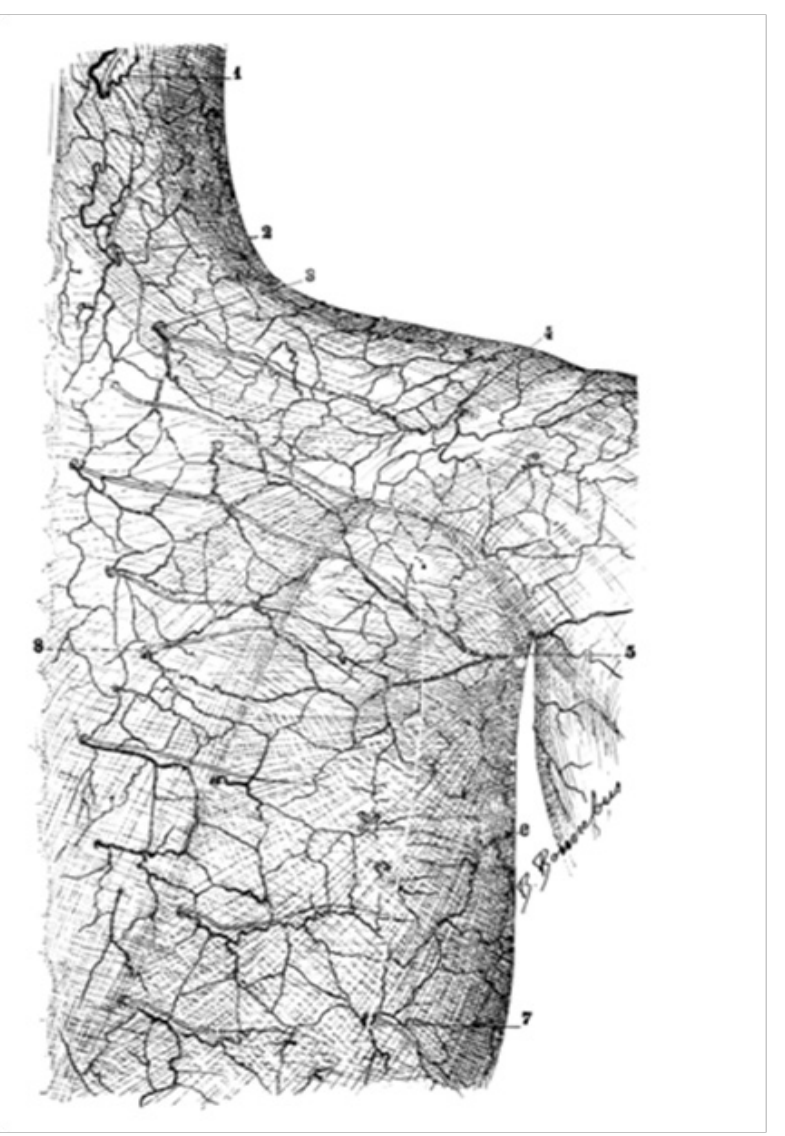

Figure I Arteries of the skin of the nuchal, scapular and dorsal regions. I: branch of the occipital artery; 2: branch of the deep cervical artery; 3: branch of the dorsal scapular artery; 4 : branch of the trapezian artery; $5-6$ : branches of the inferior scapular artery; 7: perforating branch of the intercostal arteries; 8: intercostal musculocutaneous branch.,

The descending or spinal branch of the "posterior" scapular usually sends two or three arterioles which cross the rhomboideus and the trapezius to reach the deep surface of the integuments. These arterioles take a transverse or oblique descending direction. ${ }^{6,7}$

\section{Material and methods}

Dissection was performed in 58 anatomical regions from 32 cadavers preserved in a non-formalin solution rich in glycerine. The average age of the donors was 72 years (range, 34-90) and there were 21 males and 11 females. The cadavers had no history of surgery or deformity in the areas targeted for dissection (supraclavicular and dorsal regions). They were embalmed using a glycerin-rich, formalinfree solution to preserve tissue suppleness.

For the first stage, the cadaver was placed in dorsal decubitus and the posterior triangle (lateral cervical region) was approached to remove the clavicle. The subclavian artery and its collateral arteries were dissected, identified and marked. The collateral branches of the subclavian artery responsible for trapezius vascularization were injected with a solution containing a mixture of gelatin, methylene blue and iron powder. The cadaver was then refrozen for 24 hours.

In the second stage, the cadaver was thawed out at room temperature and then placed in ventral decubitus to dissect a perforator flap from the trapezius. For this dissection, a superficial incision was made on the lateral, caudal and cranial margins of the trapezius muscle, making sure not to penetrate the muscle layer. The superficial layer was separated from the muscle's surface and detached from caudal to cranial and from lateral to midline. During this procedure, the perforators were dissected and inventoried. Dissection of the largest perforators was then continued through the muscle while preserving the integrity of the surrounding muscles (trapezius, rhomboids, levator scapulae). The superficial layer (perforator flap) was then harvested in its entirety and subjected to angiography. In the first 13 cadavers, the trapezius muscle was also harvested in its entirety to perform angiography.

\section{Results}

On the corresponding surface of the trapezius muscle, 15 perforators (range, 5-27) on average were found on each side of the spinous process line. The extrafascial pedicle had an average length of $0.8 \mathrm{~cm}$ (range, $0.5-2.0 \mathrm{~cm}$ ) and the transmuscular pedicle had an average length of $12.13 \mathrm{~cm}$ (range, 5-19 cm).

Concerning the origin of the arteria dorsalis scapulae, our results were divided into 3 types according to the classification reported by Ikka et al. ${ }^{1}$ In 21 cases, the arteria dorsalis scapulae and the arteria transversa cervicis were born from a common trunk stemming from the subclavia arteria (type I). In 27 cases (Figure 2), the arteria dorsalis scapulae arose directly from the arteria subclavia whereas the arteria transversa cervicis originated from truncus thyrocervicalis (type II). In 10 cases (Figure 3), the dorsalis scapulae and transversa cervicis arteries represented both collateral branches of the truncus thyrocervicalis (type III). In our dissections we did not find other modalities of birth of the arteria dorsalis scapulae.

More detailed findings are shown in the Table 1 and Figure 2 and Figure 3.

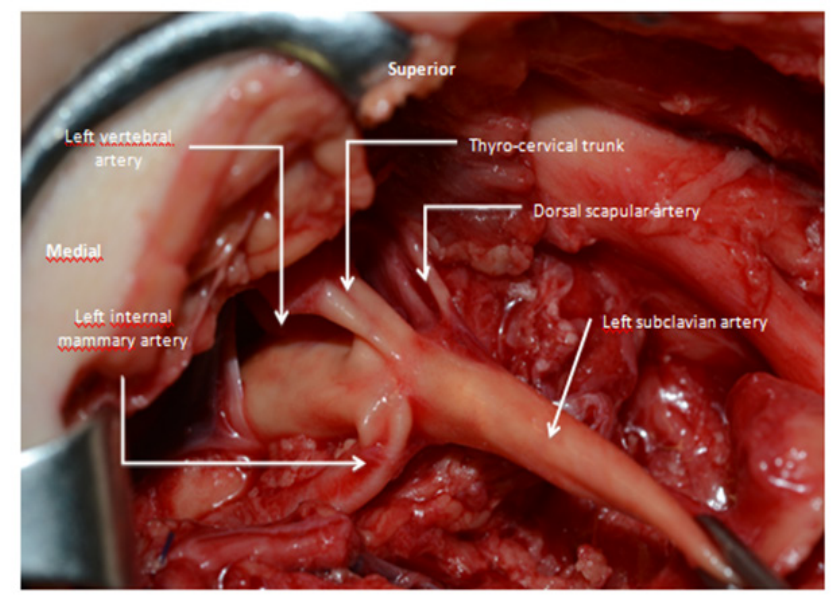

Figure 2 Birth of the dorsal scapular artery from the subclavian artery and birth of the transverse artery of the neck from the thyro-cervical trunk (Type II: found in 27 dissections out of 58). 
Table I Summary of the findings in the 58 dissected specimens

\begin{tabular}{|c|c|c|c|c|c|c|c|c|c|c|c|c|}
\hline \multirow[b]{2}{*}{$\begin{array}{l}\text { Specimen } \\
\text { number } \\
\text { by } \\
\text { order of } \\
\text { dissection }\end{array}$} & \multirow[b]{2}{*}{ Age } & \multirow[b]{2}{*}{ Sex } & \multirow[b]{2}{*}{$\begin{array}{l}\text { Number of } \\
\text { perforators } \\
\text { found }\end{array}$} & \multirow[b]{2}{*}{$\begin{array}{l}\text { Average } \\
\text { diameter } \\
(\mathrm{mm})\end{array}$} & \multirow[b]{2}{*}{$\begin{array}{l}\text { Size of } \\
\text { perforasome } \\
\text { (cm) }\end{array}$} & \multirow[b]{2}{*}{$\begin{array}{l}\text { Length of } \\
\text { extrafascial } \\
\text { pedicle } \\
(\mathrm{cm})\end{array}$} & \multirow[b]{2}{*}{$\begin{array}{l}\text { Length of } \\
\text { pedicle after } \\
\text { transmuscular } \\
\text { dissection (cm) }\end{array}$} & \multirow[b]{2}{*}{$\begin{array}{l}\text { Arc of } \\
\text { rotation } \\
\text { from } \\
\text { pivot } \\
\text { point } \\
\left({ }^{\circ}\right)\end{array}$} & \multirow[b]{2}{*}{$\begin{array}{l}\text { Distance } \\
\text { between } \\
\text { extrafascial } \\
\text { pivot } \\
\text { point and } \\
\text { spinous } \\
\text { process line } \\
\text { (cm) }\end{array}$} & \multicolumn{3}{|c|}{ Birth mode of the dorsal scapular artery } \\
\hline & & & & & & & & & & $\begin{array}{l}\text { Birth of } \\
\text { the dorsal } \\
\text { scapular } \\
\text { artery and } \\
\text { transverse } \\
\text { artery of } \\
\text { the neck } \\
\text { from a } \\
\text { common } \\
\text { trunk } \\
\text { located } \\
\text { on the } \\
\text { subclavian } \\
\text { artery } \\
\text { (Type I) }\end{array}$ & $\begin{array}{l}\text { Birth of } \\
\text { the dorsal } \\
\text { scapular } \\
\text { artery } \\
\text { from the } \\
\text { subclavian } \\
\text { artery and } \\
\text { birth of the } \\
\text { transverse } \\
\text { artery of the } \\
\text { neck from } \\
\text { the thyro- } \\
\text { cervical } \\
\text { trunk (Type } \\
\text { II) }\end{array}$ & $\begin{array}{l}\text { Birth of } \\
\text { the dorsal } \\
\text { scapular } \\
\text { artery and } \\
\text { birth of the } \\
\text { transverse } \\
\text { artery of the } \\
\text { neck from } \\
\text { a common } \\
\text { vessel } \\
\text { located on } \\
\text { the thyro- } \\
\text { cervical } \\
\text { trunk (Type } \\
\text { III) }\end{array}$ \\
\hline 1 & 67 & $\mathrm{~F}$ & 13 & 0.8 & $6 \times 7$ & 1 & 19 & 180 & 6 & $\mathrm{X}$ & & \\
\hline 2 & 88 & $\mathrm{H}$ & 10 & 0.4 & $9 \times 6$ & 0.5 & 14 & 180 & 5 & & $\mathrm{X}$ & \\
\hline 3 & 89 & $\mathrm{H}$ & 15 & 0.4 & $5 \times 7$ & 1 & 16 & 180 & 8 & $\mathrm{X}$ & & \\
\hline 4 & 90 & $\mathrm{~F}$ & 9 & 0.8 & $4 \times 8$ & 0.5 & 10 & 180 & 11 & & & $\mathrm{X}$ \\
\hline 5 & 75 & $\mathrm{~F}$ & 17 & 0.2 & $5 \times 7$ & 1.5 & 13 & 180 & 6 & & $X$ & \\
\hline 6 & 57 & $\mathrm{H}$ & 14 & 1.2 & $10 \times 9$ & 1 & 11 & 180 & 6 & & $X$ & \\
\hline 7 & 59 & $\mathrm{H}$ & 18 & 0.4 & $8 \times 5$ & 0.5 & 9 & 180 & 5 & & & $\mathrm{X}$ \\
\hline 8 & 62 & $\mathrm{H}$ & 15 & 0.4 & $8 \times 5$ & 1.5 & 16 & 180 & 7 & $\mathrm{X}$ & & \\
\hline 9 & 69 & $\mathrm{~F}$ & 16 & 0.1 & $6 \times 5$ & 1 & 7 & 180 & 5 & & $X$ & \\
\hline 10 & 65 & $\mathrm{H}$ & 9 & 0.4 & $6 \times 6$ & 0.5 & 11 & 180 & 5 & & $X$ & \\
\hline 11 & 78 & $\mathrm{H}$ & 17 & 0.8 & $8 \times 5$ & 0.5 & 10 & 180 & 6 & & $X$ & \\
\hline 12 & 73 & $\mathrm{H}$ & 18 & 0.4 & $6 \times 6$ & 1 & 16 & 180 & 7 & $\mathrm{X}$ & & \\
\hline 13 & 72 & $\mathrm{H}$ & 18 & 0.3 & $8 \times 5$ & 0.5 & 12 & 180 & 5 & $\mathrm{X}$ & & \\
\hline 14 & 88 & $\mathrm{~F}$ & 17 & 0.8 & $6 \times 8$ & 1.5 & 16 & 180 & 7 & & $\mathrm{X}$ & \\
\hline 15 & 63 & $\mathrm{H}$ & 23 & 0.5 & $8 \times 7$ & 1 & 10 & 180 & 5 & & $\mathrm{X}$ & \\
\hline 16 & 72 & $\mathrm{H}$ & 5 & 0.4 & $8 \times 5$ & 0.5 & 15 & 180 & 6 & $\mathrm{X}$ & & \\
\hline 17 & 77 & $\mathrm{~F}$ & 15 & 0.5 & $8 \times 5$ & 0.5 & 10 & 180 & 6 & $\mathrm{X}$ & & \\
\hline 18 & 58 & $\mathrm{~F}$ & 16 & 0.4 & $7 \times 6$ & 1.5 & 14 & 180 & 5 & & $X$ & \\
\hline 19 & 87 & $\mathrm{~F}$ & 16 & 0.4 & $8 \times 8$ & 0.5 & 13 & 180 & 9 & & & $\mathrm{X}$ \\
\hline 20 & 63 & $\mathrm{H}$ & 15 & 0.8 & $7 \times 7$ & 1 & 16 & 180 & 8 & $\mathrm{X}$ & & \\
\hline 21 & 64 & $\mathrm{H}$ & 17 & 1.9 & $6 \times 6$ & 0.5 & 8 & 180 & 7 & $\mathrm{X}$ & & \\
\hline 22 & 74 & $\mathrm{H}$ & 20 & 0.4 & $6 \times 8$ & 0.5 & 11 & 180 & 6 & & $X$ & \\
\hline 23 & 65 & $\mathrm{H}$ & 15 & 0.3 & $8 \times 7$ & 0.5 & 10 & 180 & 8 & & $X$ & \\
\hline 24 & 75 & $\mathrm{~F}$ & 13 & 1.3 & $10 \times 6$ & 0.5 & 7 & 180 & 10 & & $X$ & \\
\hline 25 & 90 & $\mathrm{H}$ & 13 & 0.4 & $5 \times 7$ & 0.5 & 11 & 180 & 5 & & $\mathrm{X}$ & \\
\hline 26 & 72 & $\mathrm{~F}$ & 7 & 0.4 & $5 \times 4$ & 1.5 & 16 & 180 & 5 & $\mathrm{X}$ & & \\
\hline 27 & 88 & $\mathrm{~F}$ & 17 & 0.8 & $5 \times 8$ & 2 & 13 & 180 & 6 & & & $X$ \\
\hline 28 & 69 & $\mathrm{H}$ & 18 & 0.3 & $7 \times 8$ & 0.5 & 16 & 180 & 7 & & & $X$ \\
\hline 29 & 67 & $\mathrm{H}$ & 15 & 0.3 & $5 \times 6$ & 0.5 & 16 & 180 & 5 & X & & \\
\hline
\end{tabular}




\begin{tabular}{|c|c|c|c|c|c|c|c|c|c|c|c|c|}
\hline \multirow[b]{2}{*}{$\begin{array}{l}\text { Specimen } \\
\text { number } \\
\text { by } \\
\text { order of } \\
\text { dissection }\end{array}$} & \multirow[b]{2}{*}{ Age } & \multirow[b]{2}{*}{ Sex } & \multirow[b]{2}{*}{$\begin{array}{l}\text { Number of } \\
\text { perforators } \\
\text { found }\end{array}$} & \multirow[b]{2}{*}{$\begin{array}{l}\text { Average } \\
\text { diameter } \\
(\mathrm{mm})\end{array}$} & \multirow[b]{2}{*}{$\begin{array}{l}\text { Size of } \\
\text { perforasome } \\
\text { (cm) }\end{array}$} & \multirow[b]{2}{*}{$\begin{array}{l}\text { Length of } \\
\text { extrafascial } \\
\text { pedicle } \\
\text { (cm) }\end{array}$} & \multirow[b]{2}{*}{$\begin{array}{l}\text { Length of } \\
\text { pedicle after } \\
\text { transmuscular } \\
\text { dissection (cm) }\end{array}$} & \multirow[b]{2}{*}{$\begin{array}{l}\text { Arc of } \\
\text { rotation } \\
\text { from } \\
\text { pivot } \\
\text { point } \\
\left({ }^{\circ}\right)\end{array}$} & \multirow[b]{2}{*}{$\begin{array}{l}\text { Distance } \\
\text { between } \\
\text { extrafascial } \\
\text { pivot } \\
\text { point and } \\
\text { spinous } \\
\text { process line } \\
\text { (cm) }\end{array}$} & \multicolumn{3}{|c|}{ Birth mode of the dorsal scapular artery } \\
\hline & & & & & & & & & & $\begin{array}{l}\text { Birth of } \\
\text { the dorsal } \\
\text { scapular } \\
\text { artery and } \\
\text { transverse } \\
\text { artery of } \\
\text { the neck } \\
\text { from a } \\
\text { common } \\
\text { trunk } \\
\text { located } \\
\text { on the } \\
\text { subclavian } \\
\text { artery } \\
\text { (Type I) }\end{array}$ & $\begin{array}{l}\text { Birth of } \\
\text { the dorsal } \\
\text { scapular } \\
\text { artery } \\
\text { from the } \\
\text { subclavian } \\
\text { artery and } \\
\text { birth of the } \\
\text { transverse } \\
\text { artery of the } \\
\text { neck from } \\
\text { the thyro- } \\
\text { cervical } \\
\text { trunk (Type } \\
\text { II) }\end{array}$ & $\begin{array}{l}\text { Birth of } \\
\text { the dorsal } \\
\text { scapular } \\
\text { artery and } \\
\text { birth of the } \\
\text { transverse } \\
\text { artery of the } \\
\text { neck from } \\
\text { a common } \\
\text { vessel } \\
\text { located on } \\
\text { the thyro- } \\
\text { cervical } \\
\text { trunk (Type } \\
\text { III) }\end{array}$ \\
\hline 31 & 64 & $\mathrm{H}$ & 9 & 0.8 & $6 \times 8$ & 1 & 12 & 180 & 5 & $\mathrm{X}$ & & \\
\hline 33 & 75 & $\mathrm{H}$ & 8 & 0.3 & $8 \times 6$ & 0.5 & 10 & 180 & 7 & & $\mathrm{X}$ & \\
\hline 34 & 63 & $\mathrm{~F}$ & 7 & 0.3 & $7 \times 7$ & 0.5 & 11 & 180 & 7 & $\mathrm{X}$ & & \\
\hline 35 & 81 & $\mathrm{H}$ & 11 & 0.4 & $6 \times 5$ & 0.5 & 19 & 180 & 5 & & & $\mathrm{X}$ \\
\hline 36 & 78 & $\mathrm{H}$ & 17 & 0.4 & $9 \times 5$ & 0.5 & 10 & 180 & 6 & & $X$ & \\
\hline 37 & 85 & $\mathrm{H}$ & 15 & 0.5 & $6 \times 8$ & 1 & 10 & 180 & 9 & & $\mathrm{X}$ & \\
\hline 38 & 85 & $\mathrm{H}$ & 27 & 0.4 & $6 \times 9$ & 0.5 & 16 & 180 & 6 & & $\mathrm{X}$ & \\
\hline 39 & 75 & $\mathrm{~F}$ & 15 & 0.9 & $6 \times 10$ & 1 & 9 & 180 & 6 & & $\mathrm{X}$ & \\
\hline 40 & 81 & $\mathrm{H}$ & 13 & 0.8 & $5 \times 8$ & 1 & 16 & 180 & 5 & & $\mathrm{X}$ & \\
\hline 41 & 87 & $\mathrm{~F}$ & 20 & 0.8 & $6 \times 10$ & 1 & 14 & 180 & 11 & & & $\mathrm{X}$ \\
\hline 42 & 67 & $\mathrm{~F}$ & 19 & 0.1 & $8 \times 8$ & 0.5 & 5 & 180 & 6 & $\mathrm{X}$ & & \\
\hline 43 & 82 & $\mathrm{H}$ & 16 & 0.9 & $6 \times 10$ & 1.5 & 16 & 180 & 7 & & & $\mathrm{X}$ \\
\hline 44 & 85 & $\mathrm{H}$ & 17 & 0.8 & $6 \times 10$ & 2 & 16 & 180 & 4 & & $\mathrm{X}$ & \\
\hline 45 & 69 & $\mathrm{~F}$ & 13 & 1.4 & $5 \times 8$ & 1 & 9 & 180 & 5 & & $\mathrm{X}$ & \\
\hline 46 & 77 & $\mathrm{~F}$ & 12 & 0.4 & $5 \times 5$ & 1 & 10 & 180 & 5 & $\mathrm{X}$ & & \\
\hline 47 & 73 & $\mathrm{H}$ & 17 & 0.4 & $7 \times 9$ & 1 & 4 & 180 & 8 & & $\mathrm{X}$ & \\
\hline 48 & 80 & $\mathrm{H}$ & 8 & 0.7 & $6 \times 6$ & 0.5 & 8 & 180 & 6 & $\mathrm{X}$ & & \\
\hline 49 & 80 & $\mathrm{H}$ & 18 & 0.3 & $7 \times 6$ & 0.5 & 10 & 180 & 5 & $\mathrm{X}$ & & \\
\hline 50 & 79 & $\mathrm{H}$ & 19 & 0.5 & $5 \times 8$ & 0.5 & 5 & 180 & 12 & $\mathrm{X}$ & & \\
\hline 51 & 69 & $\mathrm{~F}$ & 23 & 0.5 & $5 \times 8$ & 1.5 & 19 & 180 & 6 & & & $\mathrm{X}$ \\
\hline 52 & 34 & $\mathrm{H}$ & 16 & 0.4 & $6 \times 5$ & 1 & 7 & 180 & 5 & $\mathrm{X}$ & & \\
\hline 53 & 34 & $\mathrm{H}$ & 17 & 0.4 & $6 \times 9$ & 0.5 & 17 & 180 & 4 & $\mathrm{X}$ & & \\
\hline 54 & 57 & $\mathrm{H}$ & 12 & 0.8 & $6 \times 7$ & 1 & 8 & 180 & 7 & & $\mathrm{X}$ & \\
\hline 55 & 61 & $\mathrm{~F}$ & 15 & 0.4 & $5 \times 8$ & 0.5 & 14 & 180 & 5 & & $\mathrm{X}$ & \\
\hline 56 & 47 & $\mathrm{~F}$ & 15 & 0.7 & $6 \times 7$ & 0.5 & 10 & 180 & 6 & & & $\mathrm{X}$ \\
\hline 57 & 77 & $\mathrm{H}$ & 22 & 0.5 & $7 \times 5$ & 0.5 & 11 & 180 & 4 & $\mathrm{X}$ & & \\
\hline 58 & 81 & $\mathrm{H}$ & 13 & 0.5 & $6 \times 8$ & 1 & 9 & 180 & 5 & & $\mathrm{X}$ & \\
\hline
\end{tabular}




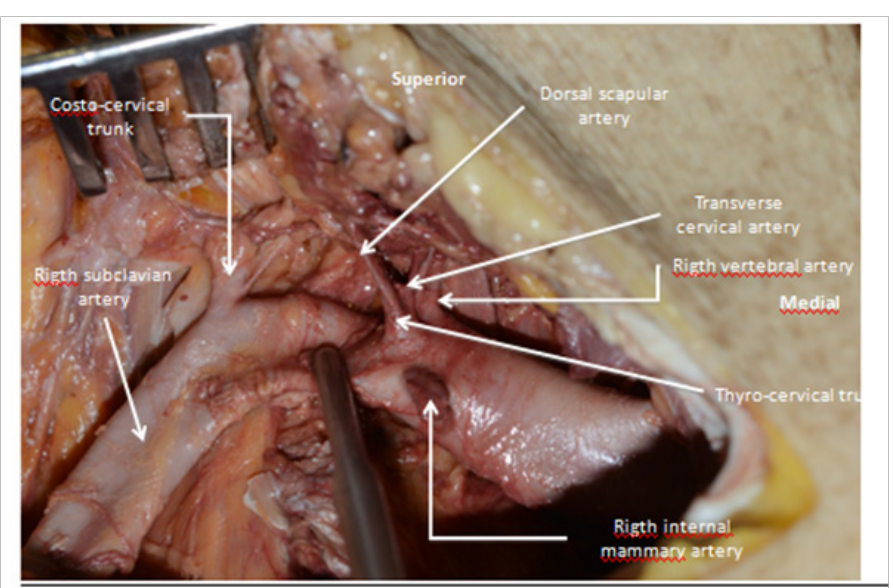

Figure 3 Birth of the dorsal scapular artery and birth of the transverse artery of the neck from a common vessel located on the thyro-cervical trunk (Type III: found in 10 out of 58 dissections).

\section{Discussion}

The dorsal scapular osteomuscular flap (DSOM flap) is a mandibular reconstruction technique that can be used when microsurgery is contraindicated. ${ }^{8}$ This flap is based on the arteria dorsalis scapulae. Harvesting it requires dissection of the cranial portion of the trapezius muscle and the rhomboideus muscle, with a significant risk of damage to the arteria transversa cervicis. This risk is to be avoided in the case where arteria dorsalis scapulae is a branch of the arteria transversa cervicis.

For a long time authors such as Beaunis, ${ }^{9}$ Sappey $^{5}$ and Poirier ${ }^{10}$ defended contradictory theories concerning the origin of the arteria dorsalis scapulae. There is considerable confusion regarding the origin of the arteria dorsalis scapulae. Not insignificant variations are reported by Ikka et al. ${ }^{1}$

Indeed, Ikka et al. ${ }^{1}$ classified their results into 3 types according to the mode of birth of arteria dorsalis scapulae. The arteria dorsalis scapulae and the arteria transversa cervicis had a common origin on the subclavia arteria (type I) in 19 cases (38\%). The arteria dorsalis scapulae was born from the arteria subclavia, while the arteria transversa cervicis was born from the truncus thyrocervicalis (type II) in 19 cases (38\%). In 12 cases (24\%) the arteria dorsalis scapulae and the arteria transversa cervicis had a common origin on the truncus thyrocervicalis (type III). Their radiographic study reported a predominance of types I (56.5\%) and II (28.3). Our results were also classified according to these three types, but the values are different. Despite these important variations, it appears from Ikka's et al. ${ }^{1}$ that the arteria dorsalis scapulae is born directly from subclavia arteria in the majority of cases.

In the literature two arteries are known to be the main sources of the arteria dorsalis scapulae: the arteria transversa cervicis and the arteria subclavian. ${ }^{11,12}$ According to many references and scientific publications, and according to the 1989 edition of the Nomina Anatomica, the arteria transversa cervicis is even the main source vessel of the arteria dorsalis scapulae (also called "rhomboidal artery" at that time) ${ }^{12-15}$ Concerning its origin, the "artery of the rhomboid muscles" represents the deep branch of division of the arteria transversa cervicis (the superficial branch going towards the trapezius muscle is still called "trapezian artery"), going below the cranial portion trapezius muscle. It ends on the rhomboid muscles. ${ }^{12}$ Under these circumstances, the rhomboid artery was called the "deep branch of the arteria transversa cervicis". However, alternatively it has been shown that the rhomboidal artery could be born from the middle or distal thirds of the arteria subclavia.

For a long time the terminology of the vascular sources of the muscles rhomboidei and trapezius was confused. This confusion was due to the fact that for each artery 2 names were used in relation to the anatomical variations in their respective origins. According to the revision of Paris concerning this terminology. ${ }^{16}$ The arteria transversa cervicis, resulting from the truncus thyrocervicalis, is divided into 2 branches: one superficial for the trapezius muscle and the other deep ending on the 2 rhomboid muscles. However, when these two branches are born separately, the trapezius muscle branch is called the "superficial cervical artery", and the branch ending on the rhomboid muscles is called the "descending scapular artery". Thus, each of these vessels has 2 different names according to its origin. This goes against the principles of the latest anatomical nomenclature. ${ }^{16}$

One of the principles adopted by the International Committee for Anatomical Nomenclature was that "anatomical structures that are topographically close should as far as possible bear similar names". ${ }^{11}$ Given that the two arteries most often have separate origins, Huelke $^{11}$ was the first to propose an appropriate terminology: the term "transverse artery of the neck" is applied to the vessel that irrigates the trapezius muscle (and whose origin is represented by truncus thyrocervicalis in $75 \%$ of cases); and the artery which irrigates the rhomboid muscles takes the name of the nerve from which it follows the path (dorsal scapular nerve), and is therefore designated under the name of arteria dorsalis scapulae. ${ }^{11,16}$ However, unlike Huelke ${ }^{11,16}$ Anglo-American literature considers a separate origin of these two arteries as exceptional. In Germanic literature this separate origin is rather typical. In French literature it appears that trapezius and rhomboid muscles receive their vascularization from the last collateral branch of the subclavian artery: the arteria dorsalis scapulae. ${ }^{11,16}$ According to the international principles of anatomical nomenclature, the name "rhomboidal artery" must remain invariable irrespective of its origin, but in relation to the anatomical structures to which it is devolved. ${ }^{11,16}$

In the work of Huelke $\mathrm{e}^{11,16}$ the arteria dorsalis scapulae is more a direct branch of the subclavia arteria than a collateral branche of the arteria transversa cervicis. This last case represents an anatomical variation and not a usual case. When the arteria dorsalis scapulae is born in the 2nd and 3rd thirds of the subclavia arteria, it is more in the form of an isolated vessel than as a common trunk with other branches. It is rare that arteria dorsalis scapulae is born from the first third of the subclavia arteria, the axillary artery and the truncus thyrocervicalis. ${ }^{11,16}$

Our work shows, as in Huelke, ${ }^{11,16}$ that most branches of the transverse cervicis and dorsalis scapulae arteries originate near the cranial edge of the scapula, laterally to the levator scapulae muscle. Usually these collateral branches are thin. Of these 2 vessels evoked, the arteria transversa cervicis is the one that most frequently presents collateral branches.

In the majority of cases dissected by Huelke ${ }^{11,16}$ the arteria dorsalis scapulae gives rise to a muscular perforating artery. This vessel is born from the arteria dorsalis scapulae at the base of the spine of the 
scapula. It travels 1 to $3 \mathrm{~cm}$ inside the medial spinal margin of the scapula, then penetrates and crosses the 2 rhomboid muscles from the depth to the surface. It thus gains the deep face of the trapezius muscle into which it penetrates at its transversal or lower portion. This muscular perforator is always born from the arteria dorsalis scapulae, and never from the arteria transversa cervicis. Given the frequency of appearance of this muscle perforator vessel, Huelke ${ }^{11,16}$ concludes that it is important for the plastic surgeon.

In spite of the well-founded arguments of Huelke, ${ }^{11,16}$ the literature is not unanimous about the predominant origin of the arteria dorsalis scapulae in the arteria subclavia. Moreover, several studies ${ }^{13,14}$ suggest that the birth of the arteria dorsalis scapulae is done at equal frequency on both arteria subclavia and arteria transversa cervicis.

The results reported by Reiner et al. ${ }^{17}$ invalidate this assertion. Because they also found the subclavia and the transversa cervicis arteries as the main sources of the arteria dorsalis scapulae. However, they show an important predominance of the subclavia arteria as source vessel ( $75 \%$ against $25 \%)$.

These differences probably correspond to racial variations, as the study populations were different (respectively black African, Asian and Caucasian). Our work on the mode of birth of the arteria dorsalis scapulae reports the following results: in 21 cases, the arteria dorsalis scapulae and the arteria transversa cervicis were born from a common trunk stemming from the arteria subclavia (type I); in 27 cases, the arteria dorsalis scapulae was born directly from the arteria subclavia whereas the arteria transversa cervicis came from the truncus thyrocervicalis (type II); in 10 cases, the dorsalis scapulae and transversa cervicis arteries represented both of the collateral branches of the truncus thyrocervicalis (type III).

In view of our results and those of similar studies, it appears that the predominant origin of the arteria dorsalis scapulae is represented by the arteria subclavian..$^{11,13,14,16}$ However it would be interesting to correlate the vascular origin of the arteria dorsalis scapulae to its initial size. Reiner ${ }^{17}$ and Ikka $^{1}$ provide a first element of answer to this possible correlation by asserting that when it is born from a collateral branch of the arteria subclavia (truncus thyrocervicalis or arteria arteria transversa cervicis), the arteria dorsalis scapulae has a smaller size than when it was born directly from the arteria subclavia. Although this correlation seems logical to us considering the vascular flow in the vessel of origin, we think that this parameter should be taken into account during the realization of a Doppler ultrasound or a preoperative arteriography in prelude to a flap's harvesting (perforating or not) of the trapezius muscle.

The arteria dorsalis scapulae irrigates the 2 rhomboid muscles, the levator scapulae muscle and the trapezius muscle. If the origin of the arteria dorsalis scapulae is inconstant, many works of anatomy ${ }^{18,19}$ and similar works ${ }^{11,16,17}$ have described this artery as being typically coming from the arteria subclavia, and its other possible origins as anatomical variations. The racial factor has been mentioned in several studies. The anatomical variations of the origin of the arteria dorsalis scapulae have been studied in several types of populations: American, ${ }^{20,21}$ European, ${ }^{13}$ and even Japanese. ${ }^{14}$

While it is true that most authors - including us - report a predominant origin of the arteria dorsalis scapulae on a vessel other than the arteria transversa cervicis, these authors also agree that the main origin is subclavian. However there are discrepancies as to the exact portion of the subclavia arteria concerned. Some authors find a higher percentage for the 2nd third, while others prefer the 3rd third of the arteria subclavia.

Chaijaroonkhanarak et al. ${ }^{22}$ report that in the Thai population, the arteria dorsalis scapulae is mainly born from the arteria transversa cervicis (as a deep branch) in $69 \%$ of cases, in $28.2 \%$ it is born from the 2 nd portion of the arteria subclavia and in $2.8 \%$ of cases it emerges from the third portion of the latter. In the work of Chaijaroonkhanarak et al. ${ }^{22}$ no significant difference was found between left and right dorsalis scapulae arteries. The frequency of the arteries dorsalis scapulae is more important in men than in women, as well on the left side as on the right. These findings are consistent with those reported by Adachi ${ }^{14}$ and Kodama ${ }^{23}$ on the Japanese population. Contrary to these 2 Asian studies (Adachi and Kodama), older works ${ }^{11,24}$ as well as a more recent study ${ }^{17}$ carried out on a Caucasian population, revealed that in $50 \%$ of cases the arteria dorsalis scapulae was born from the arteria subclavia. Moreover, Thompson ${ }^{13}$ had previously reported that in Caucasian subjects the arteria dorsalis scapulae was also frequently produced from the arteria subclavia and the arteria transversa cervicis. Our work, which has also exploited a Caucasian population, nevertheless presents results different from those of Thompson. ${ }^{13}$ Despite these discrepancies, it appears that the observed anatomical variations on the origin of the arteria dorsalis scapulae are at least partly related to racial factors.

Vascular anatomical variations can also be explained by embryological factors. Originally, the thoracic bud receives its vascularization through intersegmental arteries organized in a primitive capillary plexus. The left subclavian arteria develops from the 7 th left intersegmental artery. The proximal part of the right subclavian arteria develops from the 4th aortic arch and its distal part develops from the right dorsal aorta and the 7 th intersegmental artery. ${ }^{25}$ Thus, variations observed on the origin of the arteria dorsalis scapulae may be due to abnormalities of collateral formation of the 2 subclavian arteries. These abnormalities would then occur between the 4th and 6th week of the embryonic life, during the formation of the arterial system. ${ }^{25,26}$ Due to the multiple and plexiform sources of the subclavia arteria and its branches, many variations are possible. These variations include an inversion of the proximal-distal order of appearance of the collateral branches of the subclavian artery, and the existence of aberrant vessels anastomosing with conventional collateral branches.

\section{Conclusion}

Despite the fact that anatomical variations on small arterial branches such as the arteria dorsalis scapulae do not have any functional consequences, they can nonetheless have a significant impact on certain surgical procedures and their consequences. Indeed, the knowledge of these anatomical variations makes it possible to improve the design of regional flaps devolving to the arteria dorsalis scapulae. This knowledge also helps to prevent the post-operative complications of the reconstruction surgery of the head, neck, and the most cranial part of the back.

\section{Acknowledgments}

None

\section{Conflict of interest}

The authors declare that they have no conflicts of interest regarding this study. 


\section{References}

1. Ikka L, Mihalea C, Achour NB, et al. The origin of the dorsal scapular artery: anatomic variations and surgical applications. Surg Radiol Anat. 2016;38(9):1021-1027.

2. Angrigiani C, Grilli D, Karanas YL, et al. The dorsal scapular island flap: an alternative for head, neck, and chest reconstruction. Plast Reconstr Surg. 2003;111(1):67-78.

3. Mathes SJ, Nahai F. Classification of the vascular anatomy of muscles: experimental and clinical correlation. Plast Reconstr Surg. 1981;67(2):177-187.

4. Haas F, Weiglein A, Schwarzl F, et al. The lower trapezius musculocutaneous flap from pedicled to free flap: anatomical basis and clinical applications based on the dorsal scapular artery. Plast Reconstr Surg. 2004;113(6):1580-1590.

5. Sappey PC. Traité d'anatomie descriptive. France: Victor Masson; 1875.

6. Salmon M, Grégoire R. Artères de la peau. Paris: Masson; 1936:123131.

7. Salmon M, Dor J. Les artères des muscles des membres et du tronc. Paris: Masson; 1933.

8. Vacher C. The osteo-muscular dorsal scapular (OMDS) flap. Anatomic basis of a new pedicled flap for mandibular reconstruction. Surg Radiol Anat. 2008;30(3):233-238.

9. Beaunis H, Bouchard A. Précis d'anatomie et de dissection. France: Baillière; 1877:231-214.

10. Poirier P, Charpy A, Nicolas A, et al. Traité d'anatomie humaine. Bataille: Masson; 1899.

11. Huelke DF. A study of the transverse cervical and dorsal scapular arteries. Anat Rec. 1958;132(3):233-245.

12. Goss CM. Gray's anatomy of the human body. Academic Medicine. 1960;35(1):90.

13. Thomson A. Second annual report of the committee of collective investigation of the anatomical society of Great Britain and Ireland for the year 1890-91. J Anat Physiol. 1891;26(Pt 1):76-93.

14. Adachi B. Anatomie der Japaner I. Das arterien system der Japaner. Kyoto: Kaiserlich-japanische Universität zu Kyoto; 1928:20-71.

15. Congress of Anatomists 1989 Nomina Anatomica. Twelfth International Congress of Anatomists in London, London: Churchill Livingstone; 1985 .

16. Huelke DF. The dorsal scapular artery-a proposed term for the artery to the rhomboid muscles. Anat Rec. 1962;142(1):57-61.

17. Reiner A, Kasser R. Relative frequency of a subclavian vs. a transverse cervical origin for the dorsal scapular artery in humans. Anat Rec. 1996;244(2):265-268.

18. Woodburne RT, Burkel WE. Essentials of human anatomy. UK: Oxford, Oxford University Press; 1994.

19. Netter FH, Hansen JT, Lambert DR. Netter's clinical anatomy. USA, New Jersey: Icon Learning Systems; 2005:668 p.

20. Degaris CF. Patterns of branching of the subclavian artery in white and negro stocks. American Journal of Physical Anthropology. 1924;7(1):95-107.

21. Dasler EH. Surgical anatomy of the subclavian artery and its branches. Surg Gynecol Obstet. 1959;108(2):149-174.

22. Chaijaroonkhanarak W, Kunatippapong N, Ratanasuwan S, et al. Origin of the dorsal scapular artery and its relation to the brachial plexus in Thais. Anat Sci Int. 2014;89(2):65-70.

23. Kodama K. Arteries of the upper limb. Anatomic Variations in Japanese. 2000 .

24. Rohlich K. Uber die Arteria transversa colli des Menschen. Anat Anz. 1934;79:37-52.

25. Sadler TW. Langman's medical embryology. USA: Lippincott Williams \& Wilkins; 2011:384 p.

26. Freeman WH, Bracegirdle B. Atlas of embryology. 1970. 